\title{
Reduction of Nitroaromatic Compounds by Fe(II) Species Associated with Iron-Rich Smectites
}

\author{
Thomas B. Hofstetter*, Anke Neumann, and René P. Schwarzenbach
}

Swiss Federal Institute for Environmental Science and Technology (EAWAG) and Swiss Federal Institute of Technology (ETH), P.O. Box 611, CH-8600 Dübendorf, Switzerland

\section{Pages: 8}

Figures: 2

Tables: 2

\section{Contents:}

1. Preparation of reduced smectite suspensions

2. Modeling approach

3. Figures $\mathrm{S} 1, \mathrm{~S} 2$

4. Table S1, S2

5. Literature cited 


\section{Preparation of reduced smectite suspensions}

Nontronite (ferruginous smectite, SWa-1) and montmorillonite (Arizona montmorillonite, SAz-1) were purchased from the Source Clay Minerals Repository (University of Missouri, Columbia, MO). The clay particles were fractionated to $<2 \mu \mathrm{m}$ and freeze-dried. Clay mineral suspensions were prepared in an anaerobic glovebox $\left(\mathrm{N}_{2} / \mathrm{H}_{2}\right.$ atmosphere, ALK 421; Coy Laboratory Products Inc., Grass Lake, MI). Nanopure water (Barnstead), sodium citrate solution (0.3 M), methanol, $\mathrm{HCl}(1 \mathrm{M})$, washing solutions for the clays ( $1 \mathrm{M} \mathrm{CsCl}, \mathrm{KCl}, \mathrm{NaCl}, \mathrm{CaCl}_{2}$ ), and zwitterionic buffers (MOPS, 3-(N-morpholino)propanesulfonic acid and PIPES, piperazine-N,N'-bis(2-ethanesulfonic acid) were deoxygenated by boiling and subsequent purging with Ar for at least $3 \mathrm{~h}$. Minerals, $\mathrm{Na}_{2} \mathrm{~S}_{2} \mathrm{O}_{4}, \mathrm{NaHCO}_{3}$, and $\mathrm{KHCO}_{3}$ were transferred into the glovebox as dry solids. Bicarbonate buffers $\left(0.2 \mathrm{M} / 0.005 \mathrm{M}\right.$ of $\mathrm{NaHCO}_{3}$ or $\mathrm{KHCO}_{3}$ ) were adjusted to $\mathrm{pH} 7.5$ with deoxygenated $\mathrm{HCl}$ in the glovebox. Organic buffer solutions (MOPS, PIPES) were adjusted to the selected $\mathrm{pH}$ before purging with Ar. Oxygen-free $\mathrm{FeCl}_{2}$ solution $(0.05 \mathrm{M})$ was obtained from the oxidation of $\mathrm{Fe}(0)$ by $\mathrm{HCl}(1 \mathrm{M})$ at approx. $80^{\circ} \mathrm{C}$ for $2 \mathrm{~h}$ under $\mathrm{Ar}$ gas.

The reduction of the clay mineral suspensions was carried out following a modified version of the sodium citrate, bicarbonate, and dithionite (CBD) procedure as described earlier $(1,2)$. Briefly, assays of nontronite contained $1.25 \mathrm{~g}$ of clay mineral suspended in $66 \mathrm{~mL}$ citrate-bicarbonate buffer and were diluted with $\mathrm{H}_{2} \mathrm{O}$ to $250 \mathrm{~mL}$. To ensure that the clay was finely suspended the suspension was stirred overnight. Then $3.75 \mathrm{~g}$ of $\mathrm{Na}_{2} \mathrm{~S}_{2} \mathrm{O}_{4}$ salt were added and the reduction was stopped after 2 days by filtration. The clay was washed and homoionized by threefold filtration with $1 \mathrm{M}$ electrolyte solution $\left(\mathrm{CsCl}, \mathrm{KCl}, \mathrm{NaCl}, \mathrm{CaCl}_{2}\right)$, or alternatively by twofold ultrafiltration with a $2 \mathrm{M}$ solution $(80 \mathrm{~mL}$ ultrafiltration cell, $0.2 \mu \mathrm{m}$ Fluoropore (PTFE) membrane filters, Millipore AG; Volketswil, Switzerland) outside the glovebox under a $\mathrm{N}_{2}$ pressure of 4.5 to 5 bar. The resulting clay paste was transferred to a 50 $\mathrm{mL}$ measuring flask and resuspended in electrolyte, which yielded a clay stock suspension of $25 \mathrm{~g} \mathrm{~L}^{-1}$. $2.5 \mathrm{~mL}$ of this clay stock were transferred to $20 \mathrm{~mL}$ serum flasks and diluted with $17.5 \mathrm{~mL}$ bicarbonate buffer $\left(0.2 \mathrm{M} \mathrm{NaHCO}_{3}\right.$ or $\left.\mathrm{KHCO}_{3}\right)$ to yield a final clay concentration of $1.25 \mathrm{~g} \mathrm{~L}^{-1}$. The $\mathrm{pH}$ was adjusted 
to $7.5 \pm 0.05$ by addition of $1 \mathrm{M} \mathrm{HCl}$. The flasks were sealed with Viton ${ }^{\circledR}$ rubber stoppers and aluminum crimp caps. All assays were taken out of the glovebox (for kinetic experiments) and were mixed about their longitudinal axis on a rotator in the dark. The assays of montmorillonite contained $3 \mathrm{~g}$ of clay mineral suspended in $66 \mathrm{~mL}$ citrate-bicarbonate buffer and were diluted with $\mathrm{H}_{2} \mathrm{O}$ to $250 \mathrm{~mL}$. The preparation procedure was similar to the preparation of nontronite suspensions except for the following adjustments: the amount of reducing agent was increased to $9 \mathrm{~g} \mathrm{Na}_{2} \mathrm{~S}_{2} \mathrm{O}_{4}$ salt to ensure a ratio of 1:3 of clay to reducing agent as necessary for most efficient reduction (1); the clay stock suspension was higher concentrated $\left(60 \mathrm{~g} \mathrm{~L}^{-1}\right)$; and the assays were composed of $6 \mathrm{~mL}$ of clay stock suspension and 9 $\mathrm{mL}$ of buffer which yielded a clay concentration of $24 \mathrm{~g} \mathrm{~L}^{-1}$ in the individual assay.

\section{Modeling Approach}

Kinetic data obtained from the experiments on the adsorption and reduction of nitroaromatic compounds (NACs) in clay mineral suspensions were modeled using Aquasim modeling software (3). A detailed The reduction of a NAC to reaction intermediates as well as the reduction of the intermediates to anilines at the clay surface was assumed to follow pseudo-first order kinetics. Therefore, the following rate laws for the aqueous NAC $\left(\mathrm{NAC}_{\mathrm{w}}\right)$, intermediates $\left(\mathrm{I}_{\mathrm{w}}\right)$, and anilines $\left(\mathrm{An}_{\mathrm{w}}\right)$ were used:

$$
\begin{aligned}
& \frac{\mathrm{d}\left[\mathrm{NAC}_{\mathrm{w}}\right]}{\mathrm{dt}}=-\mathrm{k}_{\mathrm{NAC}}\left[\mathrm{NAC}_{\mathrm{w}}\right] \\
& \frac{\mathrm{d}\left[\mathrm{I}_{\mathrm{w}}\right]}{\mathrm{dt}}=\mathrm{k}_{\mathrm{NAC}}\left[\mathrm{NAC}_{\mathrm{w}}\right]-\mathrm{k}_{\mathrm{I}}\left[\mathrm{I}_{\mathrm{w}}\right] \\
& \frac{\mathrm{d}\left[\mathrm{An}_{\mathrm{w}}\right]}{\mathrm{dt}}=-\mathrm{k}_{\mathrm{I}}\left[\mathrm{I}_{\mathrm{w}}\right]
\end{aligned}
$$

where $k_{\mathrm{NAC}}, \mathrm{k}_{\mathrm{I}}$ are the rate constants for the reduction reactions of the nitrobenzene and the intermediate, respectively. Note, that $\left[I_{w}\right]$ represents the sum of the different reduction intermediates such as hydroxylamino and azo compounds and that all intermediates were assumed to be present only in the dissolved state. Data on concentration of intermediate species were only taken into account in experiments with the non-sorbing NAC, 2-acetyl nitrobenzene, for the calculation of rate constants. The total concentration of the intermediates was calculated from the difference of initial NAC concentration 
and the measured NAC and aniline concentration. The reversible adsorption of the sorbing NAC, 4acetyl nitrobenzene, to the basal clay surfaces was formulated as a transformation process transforming the aqueous species $\left[\mathrm{NAC}_{\mathrm{w}}\right]$ to the sorbed species $\left[\mathrm{NAC}_{\mathrm{s}}\right]$. Considering other conversion factors including the concentration of clay mineral particles (for details see ref (4)), sorption can be described by a dynamic sorption process with a rate of:

$$
\frac{\mathrm{d}\left[\mathrm{NAC}_{\mathrm{s}}\right]}{\mathrm{dt}}=-\mathrm{k}_{\mathrm{s}}\left(\left[\mathrm{NAC}_{\mathrm{eq}, \mathrm{s}}\right]-\left[\mathrm{NAC}_{\mathrm{s}}\right]\right)
$$

where $\left[\mathrm{NAC}_{\mathrm{s}}\right]$ represents the concentration of sorbed $\mathrm{NAC}, \mathrm{k}_{\mathrm{s}}$ is the rate constant of the sorption process. $\left[\mathrm{NAC}_{\mathrm{eq}}, \mathrm{s}\right]$ is the equilibrium concentration of sorbed $\mathrm{NAC}$, which, at low aqueous concentrations (5), can be described using a linear sorption isotherm with the adsorption constant $\mathrm{K}_{\mathrm{d}}$ as shown in equation 5 :

$$
\mathrm{K}_{\mathrm{d}}=\frac{\left[\mathrm{NAC}_{\mathrm{eq}, \mathrm{s}}\right]}{\left[\mathrm{NAC}_{\mathrm{w}}\right]}
$$

Reduction rate constants and adsorption constants were calculated for every single experiment fitting the above equations to the experimental data for NAC reduction and aniline formation. $95 \%$ confidence intervals for $\mathrm{k}_{\mathrm{NAC}}$ and $\mathrm{K}_{\mathrm{d}}$ were calculated from at least 3 replicates of kinetic experiments. 


\section{Figures}

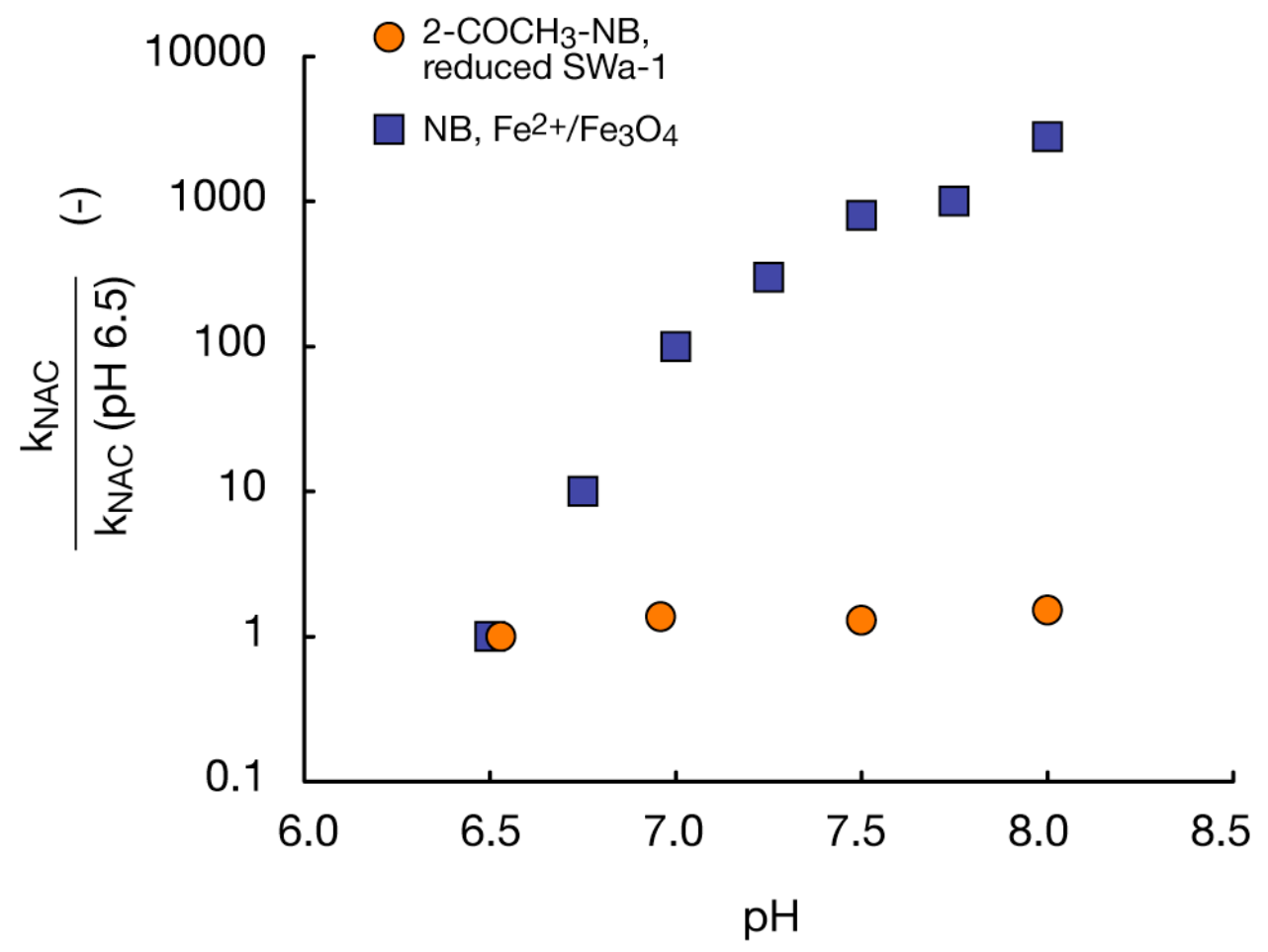

Figure $\mathrm{S} 1 \mathrm{pH}$ dependence of reduction rate constants, $\mathrm{k}_{\mathrm{NAC}}$, of 2-acetyl nitrobenzene (2- $\mathrm{COCH}_{3}$ $\mathrm{NB}$, circles) in suspensions of reduced $\mathrm{Na}^{+}$-nontronite $\left(1.25 \mathrm{~g} \mathrm{~L}^{-1}\right)$ normalized to $\mathrm{pH}$ 6.5. For comparison, normalized rate constants of nitrobenzene reduction in suspensions of $\mathrm{Fe}^{2+}$ at magnetite $\left(\mathrm{Fe}_{3} \mathrm{O}_{4}\right)$ are shown (data from ref. (6)).

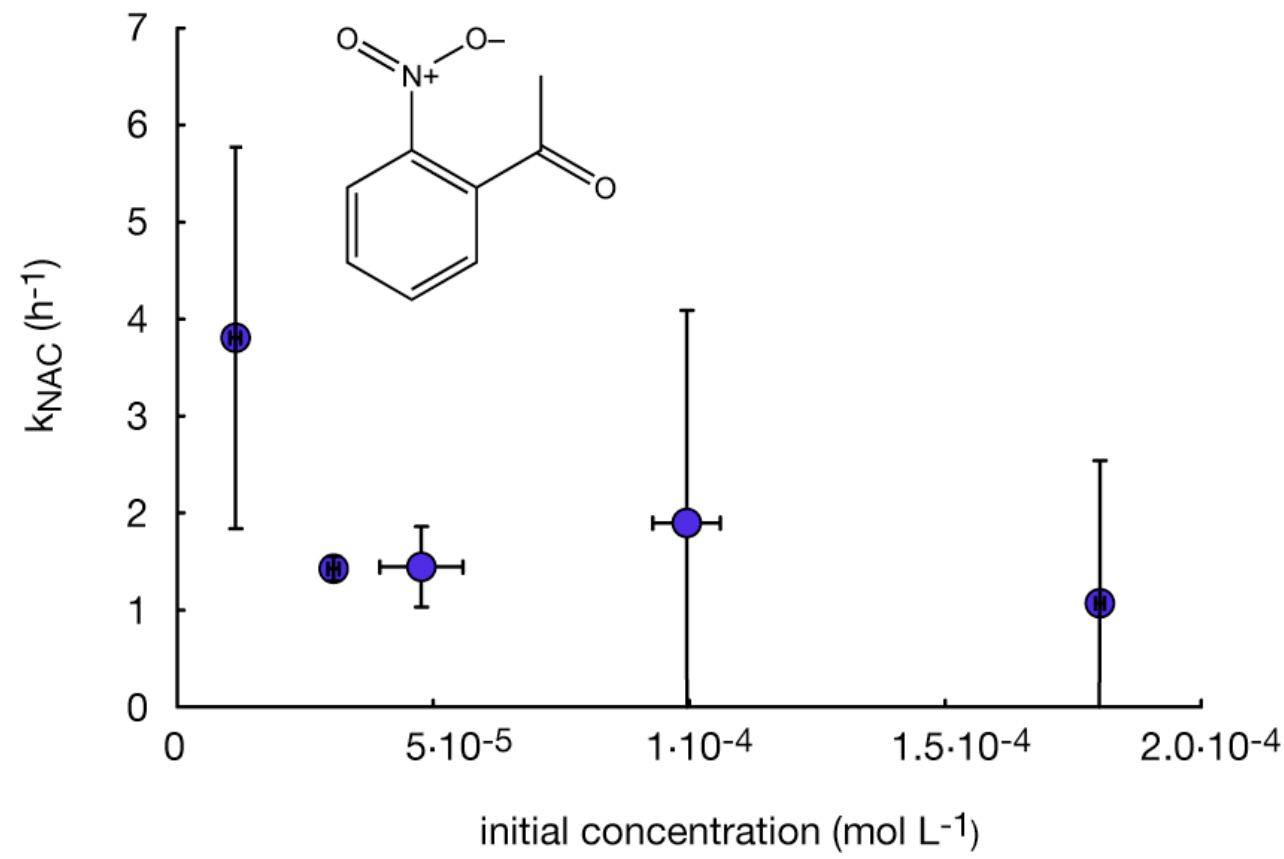

Figure S2 Effect of initial NAC concentration on the reduction rate constants, $\mathrm{k}_{\mathrm{NAC}}$, of 2-acetyl nitrobenzene (2- $\left.\mathrm{COCH}_{3}-\mathrm{NB}\right)$ in suspensions of reduced $\mathrm{Na}^{+}$-nontronite $\left(1.25 \mathrm{~g} \mathrm{~L}^{-1}\right)$ at $\mathrm{pH}$ 7.5. Error bars represent $95 \%$ confidence intervals for rate constants and initial concentrations, respectively. 


\section{Tables}

Table S1. Overview of the various Fe(II) species predominantly present at the different sites in suspensions of reduced or oxidized smectite at pH 7.5.

\begin{tabular}{|c|c|c|c|c|c|c|c|c|}
\hline \multirow{3}{*}{$\begin{array}{l}\text { Reactive } \\
\text { site }\end{array}$} & \multicolumn{7}{|c|}{ Characterization of the clay mineral suspension } & \multirow{3}{*}{$\begin{array}{c}\text { Oxidized } \\
\text { Nontronite } \\
\text { Ox. Fe } \\
\text { SWa-1 }\end{array}$} \\
\hline & \multicolumn{2}{|c|}{ Reduced Montmorillonite } & \multicolumn{5}{|c|}{ Reduced Nontronite } & \\
\hline & $\mathrm{Na}^{+} \mathrm{SAz}-1$ & $\mathrm{~K}^{+} \mathrm{SAz}-1$ & $\mathrm{Na}^{+} \mathrm{SWa}-1$ & $\mathrm{~K}^{+} \mathrm{SWa}-1$ & $\begin{array}{c}\mathrm{Na}^{+} \mathrm{SWa}-1, \\
\text { washed at } \\
\text { pH } 4\end{array}$ & $\begin{array}{c}\mathrm{K}^{+} \mathrm{SWa}-1, \\
\text { washed at } \\
\text { pH } 4\end{array}$ & $\mathrm{Fe}^{2+} \mathrm{SWa}-1$ & \\
\hline Mineral structure & $\mathrm{Fe}^{2+}$ & $\mathrm{Fe}^{2+}$ & $\mathrm{Fe}^{2+}$ & $\mathrm{Fe}^{2+}$ & $\mathrm{Fe}^{2+}$ & $\mathrm{Fe}^{2+}$ & $\mathrm{Fe}^{2+}$ & $\mathrm{Fe}^{3+}$ \\
\hline Edge surfaces & $\mathrm{Fe}^{2+}$ & $\mathrm{Fe}^{2+}$ & $\mathrm{Fe}^{2+}$ & $\mathrm{Fe}^{2+}$ & $\mathrm{Na}^{+}, \mathrm{H}^{+}$ & $\mathrm{K}^{+}, \mathrm{H}^{+}$ & $\mathrm{Fe}^{2+}$ & $\mathrm{Fe}^{2+}$ \\
\hline $\begin{array}{l}\text { Basal siloxane } \\
\text { layer / interlayer }\end{array}$ & $\mathrm{Na}^{+}$ & $\mathrm{K}^{+}$ & $\mathrm{Na}^{+}$ & $\mathrm{K}^{+}$ & $\mathrm{Na}^{+}$ & $\mathrm{K}^{+}$ & $\mathrm{Fe}^{2+}$ & $\mathrm{Na}^{+}$ \\
\hline
\end{tabular}


Table S2. Reduction equivalents quantified as reactive $\mathrm{Fe}^{2+}$ available for the reduction of acetyl nitrobenzenes in suspensions of reduced nontronite (SWa-1, $\left.1.25 \mathrm{~g} \mathrm{~L}^{-1}, \mathrm{pH} 7.5\right)$

\begin{tabular}{|c|c|c|c|c|c|c|c|c|c|c|}
\hline \multirow[t]{2}{*}{$\begin{array}{l}\text { Suspension } \\
\text { pretreatment }\end{array}$} & \multicolumn{2}{|c|}{$\begin{array}{l}\text { Kinetic experiment: } \\
\text { reactive } \mathrm{Fe}^{2+\mathrm{a}}\end{array}$} & \multicolumn{2}{|c|}{$\begin{array}{l}\text { Total reduction } \\
\text { capacity: } \\
\text { reactive } \mathrm{Fe}^{2+\mathrm{a}}\end{array}$} & \multicolumn{2}{|c|}{$\mathrm{Fe}^{2+}{ }_{\text {aq }}$ at $\mathrm{pH} 7.5$} & \multicolumn{2}{|c|}{$\mathrm{Fe}^{2+}{ }_{\text {aq }}$ at $\mathrm{pH} 4.0$} & \multicolumn{2}{|c|}{$\begin{array}{c}\mathrm{Fe}^{2+}{ }_{\text {aq }} \text { recovered w/ } 1 \mathrm{M} \\
\mathrm{CaCl}_{2}\end{array}$} \\
\hline & 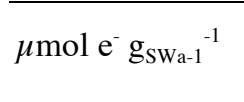 & $\begin{array}{c}\% \text { of total } \\
\mathrm{Fe}^{\mathrm{b}}\end{array}$ & $\mu \mathrm{mol} \mathrm{e}^{-} \mathrm{g}_{\mathrm{sWa}-1}{ }^{-1}$ & $\begin{array}{c}\% \text { of total } \\
\mathrm{Fe}^{\mathrm{b}}\end{array}$ & 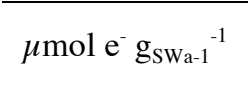 & $\begin{array}{c}\% \text { of total } \\
\mathrm{Fe}^{\mathrm{b}}\end{array}$ & 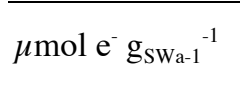 & $\begin{array}{c}\% \text { of total } \\
\mathrm{Fe}^{\mathrm{b}}\end{array}$ & $\mu \mathrm{mol} \mathrm{e}^{-} \mathrm{g}_{\mathrm{swa}-1}{ }^{-1}$ & $\begin{array}{c}\% \text { of total } \\
\mathrm{Fe}^{\mathrm{b}}\end{array}$ \\
\hline $\mathrm{Na}^{+}$exchange & 240 & 10.6 & 760 & 34 & 9 & 0.4 & 130 & 5.6 & 44 & 2.0 \\
\hline $\begin{array}{l}\mathrm{Na}^{+} \text {exchange at } \mathrm{pH} \\
4\end{array}$ & & & 730 & 32 & & & & & & \\
\hline $\mathrm{K}^{+}$exchange & & & 830 & 37 & 9 & 0.4 & 140 & 6.3 & 72 & 3.2 \\
\hline $\mathrm{K}^{+}$exchange at $\mathrm{pH} 4$ & & & 560 & 25 & & & & & & \\
\hline $\begin{array}{l}\mathrm{Fe}^{2+} \text { exchange, final } \\
\mathrm{Fe}^{2+}{ }_{\text {aq }}<10 \mu \mathrm{M}\end{array}$ & & & 480 & 21 & & & & & & \\
\hline $\begin{array}{l}\mathrm{Fe}^{2+} \text { exchange, final } \\
\mathrm{Fe}^{2+}{ }_{\text {aq }}=1 \mathrm{mM}\end{array}$ & & & 730 & 32 & & & & & & \\
\hline
\end{tabular}




\section{Literature cited}

(1) Stucki, J. W.; Golden, D. C.; Roth, C. B., Preparation and handling of dithionite-reduced smectite suspensions. Clays and Clay Minerals 1984, 32, 191-197.

(2) Hofstetter, T. B.; Schwarzenbach, R. P.; Haderlein, S. B., Reactivity of Fe(II) species associated with clay minerals. Environ. Sci. Technol. 2003, 37, 519-528.

(3) Reichert, P., Aquasim - a Tool for Simulation and Data-Analysis of Aquatic Systems. Wat. Sci. Technol. 1994, 30, 21-30.

(4) Reichert, P. "AQUASIM 2.0 - Computer program for the identification and simulation of aquatic systems," Swiss Federal Institute of Environmental Science and Technology (EAWAG), 1998.

(5) Haderlein, S. B.; Schwarzenbach, R. P., Adsorption of substituted nitrobenzenes and nitrophenols to mineral surfaces. Environ. Sci. Technol. 1993, 27, 316-326.

(6) Klausen, J.; Tröber, S. P.; Haderlein, S. B.; Schwarzenbach, R. P., Reduction of substituted nitrobenzenes by $\mathrm{Fe}(\mathrm{II})$ in aqueous mineral suspensions. Environ. Sci. Technol. 1995, 29, 2396-2404. 